\title{
EKSISTENSI LEMBAGA SWADAYA MASYARAKAT DI KALIMANTAN BARAT
}

\section{THE EXISTENCE OF NON GOVERNMENTAL ORGANIZATION IN WEST KALIMANTAN}

\author{
Sorni Paskah Daeli \\ Badan Penelitian dan Pengembangan Kementerian Dalam Negeri \\ Jalan Kramat Raya No.132 Jakarta Pusat \\ e-mail: sornipaskah@yahoo.com
}

Diterima: 13 Januari 2012, Direvisi: 25 Januari 2012, Disetujui: 27 Februari 2012

\begin{abstract}
Abstrak
Penelitian ini dilakukan untuk mengidentifikasikan faktor-faktor penyebab penyimpangan peran Lembaga Swadaya Masyarakat (LSM) di Kalimantan Barat. Metode pendekatan yang digunakan adalah deskriptif kualitatif. Informan meliputi aparat Pemerintah Daerah dan masyarakat. Hasil penelitian menunjukkan bahwa faktor-faktor menyebabkan penyimpangan peran LSM, antara lain: mencari motif keuntungan; ketiadaan sumber dana dan rendahnya profesionalisme; ideologi yang tidak jelas; regulasi yang terlalu longgar. Upaya-upaya yang dilakukan untuk mengembalikan peran LSM, antara lain LSM harus melakukan perubahan mendasar demi meningkatkan kapasitasnya dan LSM harus membangun kredibilitas dan identitasnya di mata masyarakat dan pemerintah
\end{abstract}

Kata kunci: perkumpulan, pemerintah daerah.

\begin{abstract}
This study was conducted to identify the cause factors on the role deviation of Non Governmental Organization (NGO) in West Kalimantan. The method of approach used is descriptive qualitative method. Informants that included are local government officials and public source. The results showed that some of the factors that cause deviations role of NGOs, are: profiteering motives; lack of funds and lack of professionalism, the ideology is unclear; loose regulations. Efforts that should be made to restore the role of NGOs, includes fundamental changes that NGOs must make in order to enhance its capacity and establish NGOs credibility and credentials in the society and government view.

Keywords: association, local government.
\end{abstract}

\section{PENDAHULUAN}

Ruang politik yang terbuka lebar pasca Orde Baru, telah memberikan kebebasan dan kesempatan pada berbagai kelompok masyarakat untuk berekspresi dalam wujud Organisasi Masyarakat (Ormas) dan Lembaga Swadaya Masyarakat (LSM) dengan mengusung berbagai asas dan tujuan yang berbeda-beda. Data Ditjen Kesbangpol memperlihatkan bahwa perkembangan jumlah LSM sangat pesat, di mana jika pada tahun 2002 ditaksir ada sekitar 13.000-14.000 LSM, maka pada tahun 2011 ada 65.577 LSM beroperasi di Indonesia, baik di tingkat nasional, provinsi maupun kabupaten. Ditambah bahwa keberadaan LSM yang begitu banyak telah menunjukkan tidak adanya lagi hegemoni ideologi yang dijalankan lewat berbagai peraturan perundang-undangan yang mendudukkan Pancasila sebagai satu-satunya asas bagi setiap organisasi seperti pada masa Orde Baru yang menyebabkan aktifitas LSM dan Ormas berada dalam ruang yang terbatas.

Secara umum, menurut Setyono (2003), LSM merupakan lembaga/ organisasi non partisan yang berbasis pada gerakan moral (moral force) yang memiliki peran penting dalam penyelenggaraan pemerintahan dan kehidupan politik. LSM dipandang mempunyai peran strategis dalam proses demokratisasi. Jenis organisasi ini diyakini memiliki fungsi dan karakteristik khusus dan berbeda dengan organisasi pada sektor politik-pemerintah maupun swasta (private sector), sehingga mampu menjalankan tugas tertentu yang tidak dapat dilaksanakan oleh organisasi pada dua sektor itu.

Berbeda dengan organisasi politik yang berorientasi kekuasaan dan swasta yang berorientasi komersial, secara konsepsional, LSM yang berkarakteristik: nonpartisan; tidak mencari keuntungan ekonomi; bersifat sukarela; dan bersendi pada gerakan moral; dan dapat bergerak secara luwes tanpa dibatasi oleh ikatan-ikatan motif politik dan ekonomi. Karakteristik inilah yang membuat LSM dapat menyuarakan aspirasi dan melayani kepentingan masyarakat yang luput dari perhatian sektor politik dan swasta. Kemunculan LSM merupakan reaksi atas melemahnya peran kontrol lembaga-lembaga negara, termasuk partai politik, dalam menjalankan fungsi pengawasan ditengah dominasi pemerintah terhadap masyarakat, sehingga pada awal sejarah perkembangan lahirnya LSM, terutama yang bergerak dibidang sosial politik, tujuan utama pembentukan LSM adalah bagaimana 
mengontrol kekuasaan negara. Pada masa orde baru LSM menjadi sebuah kelompok kritis yang memberikan tekanan pada pemerintah, sehingga pola hubungan LSM pada masa itu digambarkan sebagai pola hubungan yang konfliktual, di mana dari sisi pemerintah juga berupaya mencampuri dan mempengaruhi organisasi, cara kerja dan orientasi LSM.

Menurut Gaffar (2006), LSM mempunyai peran yang sangat besar dalam kehidupan masyarakat dan melihat LSM sebagai alternatif untuk munculnya civil society. Di sisi lain, Hikam (1999) memandang bahwa LSM dapat memainkan peran yang sangat penting dalam proses memperkuat gerakan demokrasi melalui perannya dalam pemberdayaan civil society yang dilakukan melalui berbagai aktifitas pendampingan, pembelaan dan penyadaran. Artinya, keberadaan LSM tidak bisa dipisahkan dari civil society, karena LSM merupakan tulang punggung dari civil society yang kuat dan mandiri.

Namun fakta di lapangan, ada berbagai problematika yang melibatkan LSM, sehingga memunculkan degradasi kepercayaan publik, karena sesungguhnya banyak sekali tantangan yang harus dihadapi oleh LSM baik internal maupun eksternal. Dari sisi internal, misalnya inefisiensi manajemen, pertikaian antar aktivis, transparansi dan sebagainya. Selain itu masalah sumber dana merupakan tantangan utama yang harus dihadapi LSM, dan sudah terlihat di tingkat nasional bahwa ada LSM yang memilih merubah arah ideologis sesuai dengan penyandang dananya. Profesionalisme LSM juga patut dipertanyakan karena sudah bukan rahasia lagi banyak LSM yang tidak memiliki kantor dan sekretariat tetap yang jelas. Belum lagi standar gaji yang minimalis, sehingga banyak kalangan LSM yang memilih berkompromi dengan pemerintah ketika peluang politik tersedia. Kondisi ini menggambarkan kondisi LSM yang carut-marut, sehingga diperlukan adanya evaluasi atas kinerja LSM. Banyak LSM yang malah berperan memperlemah gerakan rakyat dan melakukan kegiatan yang kontra-produktif. LSM seperti ini bukannya menjadi tulang punggung civil society, namun sebaliknya justru malah memperlemah. Penyimpangan perilaku LSM dan berbagai permasalahan yang dihadapi LSM, menunjukkan telah terjadi pergeseran terhadap eksistensi yang seharusnya dijalankan oleh LSM dalam pola hubungannya dengan pemerintah dan masyarakat, sehingga diperlukan adanya upaya-upaya untuk memperkuat kembali eksistensi LSM dalam konteks civil society.

Kajian ini dimaksudkan untuk mengidentifikasi faktor-faktor yang menyebabkan pergeseran eksistensi LSM, sehingga dicari upaya penanggulangannya, agar LSM dapat kembali berperan bagi terwujudnya pembangunan yang berkualitas di Provinsi Kalimantan Barat.
Kajian ini menggunakan deskriptif kualitatif dengan tujuan untuk membuat gambaran secara sistematis, faktual dan akurat mengenai fakta-fakta dan sifat-sifat dan hubungan antara fenomena yang diselidiki. Kajian ini menggunakan data primer dari hasil wawancara yang melibatkan informan. Informan yang diwawancarai dalam kajian ini adalah para tokoh masyarakat antara lain: tokoh agama; pengurus LSM; kalangan perguruan tinggi; dan Pemerintah Daerah Kalimantan Barat. Teknik snowball sampling juga digunakan ketika akses ke semua daftar informan yang diteliti tidak didapat. Jadi data yang digunakan adalah data kualitatif. Selain itu, ada data sekunder berupa dokumen resmi, laporan dan studi media juga akan digunakan. Untuk pengolahan data, data yang diperoleh dianalisis secara teknik deskriptif kualitatif, yaitu dengan model interaktif dengan tahapan, yaitu melakukan reduksi data, sajian data dan penarikan kesimpulan.

Peran LSM pernah diteliti oleh Ageng Nata Praja (2009), di Kabupaten Grobogan, dengan hasil bahwa distorsi peran LSM di Kabupaten Grobogan terjadi karena ketiadaan sumber dana, rendahnya profesionalisme karena latar belakang profesi aktivis yang beraneka ragam, dan konsep idelogi yang tidak jelas. Perbedaan dengan penelitian tersebut yang merupakan keunikan kajian ini terletak pada lokasi, yakni skala provinsi dan melibatkan semua stakeholders, terlihat pada informan yang diwawancarai, sehingga lebih banyak temuan mengenai eksistensi LSM di daerah.

Seiring dengan semakin berkembang dan kompleksnya masyarakat, baik gerakan masyarakat maupun kelompok kepentingan yang lain, memperlakukan organisasi sebagai salah satu sarana perjuangan untuk mencapai tujuan atau sasaran yang disepakati. Gerakan masyarakat yang terorganisir dikenal sebagai organisasi kemasyarakatan dengan karakteristik, yaitu organisasi diluar organisasi pemerintahan, tidak bermotif keuntungan, lebih melibatkan anggota dalam kegiatannya, keanggotaan yang bersifat massal, melakukan kegiatan politis disamping perjuangan teknis keorganisasian, serta cukup berkepentingan akan ideologi (Sanit, 1985). LSM merupakan salah satu bentuk organisasi itu.

Umumnya, LSM adalah organisasi yang didirikan oleh perorangan atau kelompok orang yang secara sukarela yang memberikan pelayanan kepada masyarakat umum tanpa mencari keuntungan dari kegiatan tersebut. Sebutan LSM sendiri merupakan pengembangan dari istilah ornop (organisasi non pemerintah) yang merupakan terjemahan langsung dari istilah bahasa Inggris Non Government Organization (NGO). Dalam arti umum, LSM mencakup semua organisasi masyarakat yang berada di luar struktur dan jalur formal pemerintahan. Prinsipnya, organisasi non pemerintah dapat dilihat dengan ciri-ciri: 1) organisasi ini bukan bagian dari pemerintah; birokrasi ataupun negara; 2) tidak mencari keuntungan (nirlaba); dan 3) kegiatan 
dilakukan untuk kepentingan masyarakat umum. Di Indonesia, istilah LSM didefinisikan secara tegas dalam Instruksi Menteri Dalam Negeri (Inmendagri) Nomor 8/1990 tentang Pembinaan Lembaga Swadaya Masyarakat. Lampiran Inmendagri menyebutkan bahwa LSM adalah organisasi/lembaga yang anggotanya adalah masyarakat warga negara Republik Indonesia yang secara sukarela atau kehendak sendiri, berniat serta bergerak di bidang kegiatan tertentu yang ditetapkan oleh organisasi/lembaga sebagai wujud partisipasi masyarakat dalam upaya meningkatkan taraf hidup dan kesejahteraan masyarakat, yang menitikberatkan kepada pengabdian secara swadaya.

Bentuk LSM di Indonesia dikemukakan oleh Eldridge (dalam Nata Praja, 2009) yang membaginya dalam pendekatan berdasarkan kegiatan dan mendefinisikan gerakan LSM Indonesia menjadi dua kategori. Kategori pertama adalah LSM dengan label "pembangunan", yaitu organisasi yang memusatkan perhatiannya pada program pengembangan masyarakat konvensional, yaitu irigasi, air minum, pusat kesehatan, pertanian, peternakan, kerajinan dan bentuk pembangunan ekonomi lainnya. Kategori kedua adalah LSM "mobilisasi", yaitu organisasi yang memusatkan perhatiannya pada pendidikan dan mobilisasi rakyat miskin sekitar isu yang berkaitan dengan ekologi, hak asasi manusia, status perempuan, hak-hak hukum atas kepemilikan tanah, hak-hak pedagang kecil, tunawisma dan penghuni liar di kota-kota besar.

Selain itu, Corten (dalam Hadjar, 2006) membedakan jenis LSM ini dalam dua kategori. Jenis LSM pertama adalah LSM yang bergerak dalam bidang community development, menggunakan pendekatan mikro dalam mencoba memecahkan persoalan sosial. LSM ini suka mengerjakan proyek-proyek pemberdayaan ekonomi pedesaan, melakukan pendampingan pada industri rumah mikro dan menengah, dan percaya pada kemampuan masyarakat untuk memecahkan masalahnya sendiri. Jenis kedua adalah LSM yang bergerak pada bidang advokasi. LSM suka memberi tekanan pada kebijakan. Mereka berusaha merubah kebijakan-kebijakan penyebab ketidakadilan. Mereka percaya bahwa masalah mikro dalam masyarakat tidak dapat dipisahkan dengan masalah politik pembangunan nasional. Maka penanggulangan masalah pembangunan hanya bisa dimungkinkan jika ada perubahan struktural.

Berbicara mengenai LSM, tentunya tidak dapat dipisahkan juga dari konsep masyarakat sipil (civil society). Istilah LSM sendiri lahir dari paradigma civil society yang mengejawantah dalam berbagai wadah sosial politik di masyarakat mulai dari bidang keagamaan, profesi, paguyuban, kaum tani, buruh, pedagang dan unit-unit komunitas lainnya, domain mereka terpisah dari negara maupun sektor bisnis. LSM adalah salah satu komunitas dari masyarakat sipil yang sering menjadi perhatian, di mana sesuai karakteristiknya LSM ini biasanya membawa misi penguatan dan pemberdayaan masyarakat di luar negara dan sektor swasta, yang merupakan substansi gagasan dan praksis hidup masyarakat sipil (Hadjar, 2006).

Dalam konteks masyarakat sipil ini, menurut Einstadt (dalam Gaffar, 2006), diperlukan adanya empat persyaratan, yakni: 1) otonomi; 2) akses masyarakat terhadap lembaga negara; 3) arena publik yang bersifat otonom; dan 4) arena publik yang terbuka bagi semua lapisan masyarakat. Dalam hal ini, dipersyaratkan adanya organisasi atau kelompok kepentingan yang memiliki tingkat kemandirian yang tinggi, seperti LSM dan media massa. Dengan tingkat keleluasaan bergerak, kebebasan dan kemandirian yang cukup tinggi, LSM dapat menjadi sumber daya politik yang potensial dalam menyiapkan civil society, dalam arti sebagai suatu ruang publik antara negara dan masyarakat. Kekuasaan negara dibatasi dalam ruang publik oleh partisipasi politik masyarakat dalam rangka pembentukan kebijaksanaan publik.

Sementara itu, Meutia Ganie-Rochman (dalam Maruto \& Anwari, 2002) menyebutkan ada tiga elemen dasar civil society, yaitu: 1) orientasi bahwa prinsip-prinsip penyelenggaraan negara tidak dominan ditentukan oleh pemerintah; 2) sangat dibutuhkan keterampilan berorgani-sasi dengan prinsip demokratis; 3) keharusan adanya perilaku yang menghormati etika. Dari elemen dasar ini, poin pertama dengan jelas mengakui pentingnya keberadaan LSM (kelompok masyarakat) sebagai sumber perubahan dalam civil society.

Di Indonesia, konsep civil society belum optimal dilaksanakan. Pemerintah masih menunjukan dominasi, terutama dalam formulasi kebijakan. Sementara di tataran implementasi kebijakan sering terjadi manipulasi politik. Dalam pandangan Gramscian, dominasi dan manipulasi merupakan bentuk lain dari hegemoni. Fakih (dalam Simon, 1999) menyebutkan bahwa, kesadaran politik kritis terhadap hegemoni dominan dan sistem yang tidak adil merupakan dasar penting dalam civil society yang merupakan perkumpulan sosial politik, masyarakat adat, pesantren ataupun LSM di mana masing-masing anggotanya memiliki kesadaran kritis sebagai intelektual organik dalam suatu aksi politik.

Corrothers \& Suryatna (dalam Gaffar, 2006) mengidentifikasikan empat peranan yang dapat dimainkan oleh LSM dalam sebuah negara yaitu: 1) katalisasi perubahan sistem, yang dilakukan dengan jalan mengangkat sejumlah masalah yang penting dalam masyarakat dan melakukan advokasi semi perubahan negara; 2) memonitor pelaksanaan sistem dan penyelenggaraan negara, yang dilakukan dengan melalui penyampaian kritik atau pelaporan penyimpangan dan penyalahgunaan kekuasaan; 3) memfasilitasi rekonsiliasi warga dengan lembaga peradilan melalui aktifitas pembelaan dan pendampingan terhadap warga korban kekerasan; 4) 
implementasi program pelayanan di mana LSM dapat menempatkan diri sebagai lembaga yang mewujudkan sejumlah program.

Menurut Gaffar (2006), relasi antara negara dan LSM sama sekali tidak dapat dipisahkan. Berdasarkan sejarahnya, relasi LSM dan pemerintah mengalami pasang surut, dari hubungan yang bersifat cooperative dan partnership hingga hubungan yang sifatnya conflictual. Ryker (dalam Gaffar, 2006) menyebutkan lima model pola relasi antara LSM dengan pemerintah, yaitu: pertama, autonomous/benign neglect. Dalam pola relasi ini, pemerintah tidak menganggap LSM sebagai ancaman, karena itu membiarkan LSM bekerja secara independen dan mandiri. Model pola relasi kedua adalah facilitation/promotion. Pemerintah menganggap kegiatan LSM sebagai sesuatu yang bersifat komplementer, di mana Pemerintahlah yang menyiapkan dukungan bagi LSM untuk beroperasi, termasuk bila diperlukan menyediakan fasilitas dana, peraturan dan pengakuan hukum serta hal-hal yang sifatnya administratif lainnya. Model pola relasi ketiga adalah collaboration/ cooperation. Pemerintah menganggap bahwa bekerjasama dengan LSM merupakan sesuatu yang menguntungkan, karena dengan kerjasama semua potensi dapat disatukan dissolution seperti yang diterapkan pada masa Orde Baru. Dalam rangka mewujudkan civil society dan good governance Meuthia Ganie-Rochman (dalam Nata Praja, 2009) mengajukan beberapa hal yang harus ditangani oleh LSM. Pertama, alokasi sumber daya yang dilakukan hendaknya meliputi pelayanan publik, kontrol alokasi sumber daya di daerah, penguatan organisasi masyarakat melalui pendidikan politik, serta penguatan kedudukan kelompok masyarakat agar mampu mengontrol alokasi sumber daya keuangan dan alam. Kedua, LSM harus berada di garis depan dalam hal pembangunan hukum dan peraturan baru yang sangat dibutuhkan. Ketiga, LSM berkewajiban meningkatkan kapabilitas masyarakat dalam kehidupan politik, meliputi upaya membangun identitas kewargaan, pembentukan forum publik, dan upaya pendisiplinan berkenaan dengan terjadinya konflik.

\section{HASIL DAN PEMBAHASAN}

Berdasarkan data tahun 2009 dari Badan Kesbangpol \& Linmas, terdapat 218 organisasi non pemerintah, termasuk di dalamnya LSM yang diklasifikasikan berdasarkan jenis organisasinya adalah sebagai berikut:

Tabel 1. Jumlah LSM/Ormas Terdaftar di Provinsi Kalimantan Barat S/D Tahun 2009

\begin{tabular}{|c|c|c|c|c|c|c|}
\hline No. & Jenis Organisasi & s/d 2006 & 2007 & 2008 & 2009 & Jumlah \\
\hline 1. & Ormas Kesamaan Kegiatan & 18 & 18 & 12 & 11 & 59 \\
\hline 2. & Ormas Kesamaan Profesi & 51 & 0 & 1 & 1 & 53 \\
\hline 3. & Ormas Kesamaan Keagamaan & 14 & 4 & 0 & 1 & 19 \\
\hline 4. & Ormas Kesamaan Fungsi & 16 & 0 & 0 & 0 & 16 \\
\hline 5. & LSM & 36 & 8 & 14 & 13 & 71 \\
\hline & TOTAL & 135 & 30 & 27 & 26 & 218 \\
\hline
\end{tabular}

Sumber: Badan Kesbangpol \& Linmas Prov.Kalimantan Barat, 2011.

guna mencapai satu tujuan bersama. Model pola relasi keempat adalah cooptation/absorption. Pemerintah mencoba menjaring dan mengarahkan kegiatan LSM dengan mengatur segala aktifitas mereka. Untuk itu, LSM harus memenuhi ketentuan yang dikeluarkan pemerintah. Tidak jarang pemerintah melakukan kontrol secara aktif. Model pola relasi kelima adalah containment/sabotage/dissolution. Pemerin-tah melihat LSM sebagai tantangan bahkan ancaman, sehingga pemerintah mengambil langkah tertentu untuk membatasi ruang gerak LSM atau bahkan membubarkan LSM yang dianggap melanggar ketentuan yang berlaku.Dalam suasana reformasi saat ini, dengan kehidupan demokrasi yang berjalan lebih baik, sangat memungkinkan untuk menciptakan hubungan antara LSM dengan pemerintah yang sifatnya autonomous/benign neglect, facilitation/ promotion, dan collaboration/cooperation sekaligus, dan bukan pola relasi yang bersifat cooptation/absorption atau containment/sabotage/
Jumlah LSM di Kalimantan Barat sesungguhnya lebih dari 71 LSM, karena menurut staf Badan Kesbangpol \& Linmas yang membidangi mengenai LSM, jumlah LSM yang ada sekarang merupakan jumlah yang berhasil didata dengan cara jemput bola. Masih ada LSM lain yang belum terdata, di mana mereka umumnya hanya beroperasi dengan Akta Notaris namun tidak dilengkapi dengan Surat Keterangan Terdaftar (SKT) dari pemerintah daerah.

Gerakan LSM di Kalimantan Barat, seperti daerah lainnya, diilhami oleh keberhasilan gerakan reformasi yang berhasil mengganti rezim otoriter Orde Baru dengan Pemerintahan Reformasi yang lebih terbuka. Para aktivis LSM di Kalbar umumnya berasal dari mantan aktivis kampus pada era awal Reformasi. Setelah lulus dari berbagai perguruan tinggi sebagian dari mereka melanjutkan semangat reformasi di daerah asalnya di Kalimantan Barat. LSM-LSM yang beroperasi di Kalimantan Barat umumnya memiliki ruang lingkup kegiatan meliputi 
pemberdayaan masyarakat, penguatan hak-hak sipil, advokasi dan pendampingan, monitoring dan pengawasan kebijakan pemerintah daerah. Bentuk konkritnya, mereka menjadi mitra dalam proyekproyek pemerintah yang melibatkan masyarakat. Berbagai kegiatan seperti pembinaan, workshop, pelayanan pendidikan dan kesehatan serta proyekproyek pemberdayaan masyarakat melibatkan LSM lokal. Sementara LSM yang bergerak dalam bidang advokasi dan pengawasan, banyak melakukan kritik keras dan bersuara lantang melaporkan berbagai penyimpangan termasuk dugaan korupsi pada berbagai proyek pemerintah daerah.

Jika memotret LSM di Kalimantan Barat berdasarkan tipologi Corten, dapat diklasifikasikan menjadi dua kelompok. Kelompok pertama adalah LSM yang bergerak dalam bidang community development yang menggunakan pendekat-an mikro dalam mencoba memecahkan masalah sosial. LSM jenis ini menjadi mitra dalam proyek-proyek pemerintah. LSM seperti Lembaga Pemberdayaan Perempuan Bunga Bangsa Kalimantan Barat (LPPBB) dengan kegiatan-kegiatannya di bidang pemberdayaan masyarakat, Bina Pelestarian Alam dan Lingkungan Hidup (BIPALHI) dengan kegiatan bidang pelestarian alam, Sarana Anak Bangsa (SABANG) dengan pelayanan pendidikan, Dewan Kesehatan Rakyat Kalimantan Barat (DKRKB) dengan kegiatan bidang pelayanan masyarakat, kesehatan, sanitasi dan kebersihan, dan juga beberapa LSM lainnya yang memfokuskan diri pada peningkatan kapasitas masyarakat termasuk dalam kelompok LSM dengan kategori community development.

Kelompok kedua adalah LSM yang bergerak di bidang advokasi. Jenis LSM ini percaya bahwa untuk merubah tatanan masyarakat yang tidak adil, maka tekanan harus diberikan pada kebijakan. Mereka berusaha merubah kebijakan-kebijakan penyebab ketidakadilan. Mereka percaya bahwa masalah mikro dalam masyarakat tidak dapat dipisahkan dengan masalah politik dan pembangunan. Maka penanggulangan masalah pembangunan hanya bisa dimungkinkan jika ada perubahan struktural. LSM yang termasuk dalam kelompok ini adalah Aktualisasi Amanah Rakyat (AKAR), Gerakan Rakyat Anti Korupsi (GRAK), Komisi Pemantau Pembangunan Kalbar (KPPK), Komite Pemantau Pemilihan Kepala Daerah (KPPKD), Forum Kritisi Kinerja Aparatur Negara (FEKAN), dan LSM lainnya yang sejenis. LSM jenis ini aktif melakukan aksi-aksi yang sifatnya mengkritisi dan mengawasi implementasi kebijakan pemerintah daerah. Mereka sering berteriak keras mengecam penyimpangan yang terjadi dalam penyelenggaran pemerintahan. Berbagai ruang kebijakan publik menjadi fokus perhatian mereka, di antaranya adalah proses penyusunan dan pengalokasian anggaran APBD, pelaksanaan proyekproyek, kualitas pelayanan pendidikan dan kesehatan, sampai dengan kebijakan di bidang kepegawaian termasuk pengadaan CPNS dan kebijakan pengisian jabatan struktural di pemerintahan provinsi dan kabupaten.

Beberapa langkah kongkrit yang telah dilakukan oleh LSM-LSM jenis advokasi dan pengawasan ini di antaranya adalah dengan melaporkan beberapa kasus dugaan korupsi dan indikasi kolusi, korupsi, dan nepotisme dalam berbagai pelaksanaan kebijakan publik. Di antaranya, pada tahun 2010, LSM Forum Kritisi Kinerja Aparatur Negara (FEKAN) melaporkan kasus korupsi bantuan sosial KONI Kalimatan Barat ke Polisi Daerah Kalimatan Barat. LSM lainnya Gerakan Rakyat Anti Korupsi (GRAK) di Jakarta melaporkan dugaan korupsi Bupati Ketapang yang diduga merugikan negara Rp118 miliar, dugaan korupsi Pasar Dahlia, dan dugaan korupsi pengadaan baju hansip ke Komisi Pemberantas Korupsi (KPK). LSM lain seperti Komite Pemantau Pemilihan Kepala Daerah (KPPKD), berkaitan dengan pelaksanaan Pemilukada kabupaten/kota sempat mendesak KPUD kabupaten/kota di Kalimantan Barat untuk bertanggung jawab mengenai pelaksanaan Pemilukada yang carut-marut. KPPKD mengungkapkan tentang kepemilikan ganda kartu pemilih oleh sejumlah warga, sementara warga lain justru tidak memperoleh kartu pemilih.

Mengutip Fakih (1996) dalam pemetaan paradigma, kebanyakan LSM di Kalimantan Barat pada awalnya banyak menganut paradigma reformis, di mana semangat utamanya adalah perlunya partisipasi rakyat dalam pembangunan, bahwa keterbelakangan mayoritas rakyat disebabkan oleh adanya sesuatu yang salah dengan mentalitas dan nilai-nilai rakyat. Kegiatan LSM diwujudkan dalam upaya-upaya memotivasi rakyat agar berpartisipasi dalam pembangunan. Namun saat ini dengan semakin meningkatnya keberanian untuk mengkritisi kebijakan pemerintah, LSM-LSM berparadigma reformis sedang bergerak menjadi LSM dengan paradigma transformatoris, yang melihat kondisi struktur sosial ekonomi dan politik sebagai hasil pemaksaan negara atau kelompok-kelompok dominan, sehingga melahirkan ketidakadilan dan ketidakdemokrasian. Gerakan-gerakan LSM ini terasa agak radikal, di mana iklim atau isu keterbukaan dimanfaatkan untuk mencoba membongkar berbagai persoalan sosial, ekonomi dan politik. Oleh karena itu, isu gerakannya lebih bernuansa politik, seperti mengambil tema hak azasi manusia, kesenjangan sosial, gerakan civil society, pelibatan rakyat dalam proses-proses politik seperti demonstrasi, unjuk rasa dan mimbar bebas serta berorientasi pada kemandirian rakyat. Di Kalimantan Barat, paradigma transformatoris mulai dianut oleh LSM-LSM seperti GRAK, AKAR, KPPK, FEKAN dan LSM-LSM lain yang aktif menekan pemerintah terkait kasus-kasus penyimpangan kebijakan. 
Dalam konsep civil society, kondisi masyarakat di Kalimantan Barat sangat jauh dari prinsip kemandirian. Independensi masyarakat terhadap pemerintah, yang merupakan prinsip utama dalam membangun civil society tidak terlihat. Pemerintah daerah masih memegang kontrol penuh dalam kehidupan politik, sementara masyarakat hanya sebagai penonton atau bahkan dalam kasus tertentu sebagai obyek eksploitasi. Dominasi itu terlihat jelas dalam perumusan kebijakan, sementara dalam implementasi kebijakan banyak terjadi manipulasi yang merugikan masyarakat.

Bila dibandingkan dengan apa yang dikemukakan Einstadt (dalam Gaffar, 2006) bahwa salah satu komponen utama sebagai syarat adanya civil society, yaitu otonomi, tidak ditemukan dalam masyarakat Kalimantan Barat. Karena makna otonomi dari civil society adalah kemandirian dalam melakukan inisiatif dalam melakukan kegiatan dan kemandirian dari intervensi pemerintah, maka masyarakat harus dilibatkan dalam proses perencanaan kebijakan daerah dan di sisi lain masyarakat bebas melakukan aktifitasnya. Namun praktiknya, perumusan kebijakan hampir sepenuhnya didominasi oleh pemerintah daerah dan DPRD, sedangkan tingkat partisipasi masyarakat masih rendah. Dalam rangka penyusunan APBD, kegiatan musyawarah perencanaan pembangunan daerah (musrenbang) yang seharusnya menjadi ajang menjaring aspirasi mengenai apa yang menjadi kebutuhan masyarakat justru tidak berjalan sesuai dengan tujuannya. Proses penyusunan APBD yang di antaranya merumuskan kegiatan (proyek-proyek pembangunan baik fisik maupun non fisik), selama ini berasal dari inisiatif eksekutif dan aspirasi masyarakat yang dihasilkan dari kegiatan musrenbang mulai dari tingkat desa/kelurahan, kecamatan, kabupaten hingga provinsi. Semua usulan dan aspirasi ini masuk ke DPRD untuk dilakukan pembahasan dengan penentuan skala prioritas dan besaran anggaran. Di tingkat DPRD inilah terjadi proses komunikasi politik yang sifatnya tertutup, di mana terjadi tarik ulur kepentingan eksekutif dan legislatif. Hasilnya adalah seringkali muncul kegiatan atau proyek baru yang sebelumnya tidak pernah muncul dalam usulan hasil musrenbang, sementara hasil dari musrenbang justru diabaikan. Seorang aktivis LSM dari Aktualisasi Amanah Rakyat (AKAR) menyebutkan proyek-proyek baru ini sebagai proyek pesanan dari DPRD untuk menyebutkan betapa kuatnya pengaruh DPRD.

Kapasitas masyarakat juga berperan penting dalam mewujudkan otonomi masyarakat. Kondisi masyarakat Kalimantan Barat yang tingkat perekonomian dan kesejahteraannnya masih belum mapan bila dibandingkan dengan provinsi lainnya di Kalimantan, ditambah dengan kualiatas sumberdaya manusia yang rendah, di mana tercermin dari tingkat pendidikan masyarakat, merupakan salah satu faktor penghambat adanya otonomi masyarakat sebagai syarat adanya civil society. Faktor lainnya adalah rendahnya budaya politik sebagai akibat tidak berhasilnya pendidikan politik oleh pemerintah maupun partai politik.

Komponen civil society kedua menurut Einstadt adalah adanya akses masyarakat terhadap lembaga negara. Fakta yang terjadi adalah bahwa akses terhadap lembaga pemerintah daerah sangat minim dan terbatas. DPRD misalnya merupakan sebuah lembaga yang tertutup terhadap aspirasi masyarakat. Sebagaimana pada kasus musrenbang, DPRD seakan menutup diri terhadap inisiatif yang bersumber dari masyarakat, namun di lain pihak anggota DPRD atas nama pribadi seringkali memberikan memo rekomendasi terhadap proposal agar diprioritaskan dalam pemberian bantuan. Sementara itu, SKPD-SKPD di Kalimantan Barat juga dikeluhkan oleh kalangan aktivis LSM sebagai lembaga yang tidak melaksanakan prinsip-prinsip transparansi luas. Akses terhadap infOrmasi pelaksanaan kegiatan APBD dan besaran anggaran sangat terbatas. Begitu juga dengan permintaan datadata resmi yang lebih detail mengenai penyelenggaran kebijakan pemerintahan, harus melalui proses birokrasi dan perijinan yang rumit. Data-data mengenai pelaksanaan pengadaan barang/jasa misalnya, disinyalir banyak terjadi kecurangan-kecurangan yang ditutup-tutupi. Dari data survey Forum Kritisi Kinerja Aparatur Negara (FEKAN), sejauh ini partisipasi masyarakat dalam penyelenggaraan pemerintahan daerah masih cukup rendah. Akses infOrmasi masyarakat terhadap pengelolaan APBD baru 24,35\%, pembuatan prosedur pelayanan $30,91 \%$, dan pemberian insentif pejabat publik $18,33 \%$.

Komponen civil society yang ketiga adalah adanya arena publik yang otonom di mana masyarakat bebas berekspresi dan mengaktualisasikan diri dalam berbagai organisasi. Menurut Badan Kesbangpol \& Linmas, terjadi pertumbuhan yang cukup pesat organisasi non pemerintah termasuk LSM. Jumlah ini masih memungkinkan bertambah karena masih banyak organisasi yang belum terdaftar, dan hanya beroperasi berdasarkan Akta Notaris namun belum memiliki SKT dari pemerintah provinsi/kabupaten. Sedangkan komponen terakhir syarat adanya civil society adalah adanya area publik sebagaimana yang disebut sebelumnya yang sifatnya terbuka bagi semua lapisan masyarakat, dan tidak dijalankan secara rahasia dan eksklusif. Namun kenyataannya jarang sekali ada semacam diskusi publik, public hearing, atau penjaringan aspirasi yang menyangkut masalah publik dan melibatkan masyarakat dalam merumuskan kebijaksanaan publik.

Untuk membentuk suatu civil society di Kalimantan Barat, diperlukan suatu tatanan masyarakat yang bersifat mandiri dan terlepas dari kekuasaan negara (pemerintah daerah). LSM sebagai salah satu komponen civil society saat ini merupakan 
unsur yang potensial untuk menciptakan civil society. Kemampuan dan kemandirian LSM yang mampu mengisi ruang publik diharapkan dapat membatasi kekuasaan pemerintah, sehingga mampu menciptakan kehidupan yang demokratis. Peranan penting lainnya adalah pemberdayaan civil society yang dilakukan melalui usaha-usaha penguatan masyarakat akar rumput melalui berbagai aktivitas pendampingan dan pembelaan atas hak-hak rakyat.

Dalam konteks Kalimantan Barat, pemerintah menunjukkan dominasinya terhadap masyarakat terutama dalam hal penyusunan kebijakan publik. Pemerintah merupakan pemegang dan penentu kebijakan publik, sementara rakyat tidak dilibatkan dalam formulasi kebijakan namun dalam beberapa kasus diharuskan terlibat pada proses implementasi. Selain kasus musrenbang, dalam proses restrukturisasi organisasi perangkat daerah, misalnya proses penyusunan SOTK organisasi perangkat daerah hanya dilakukan oleh pemerintah daerah dan DPRD tanpa melibatkan kalangan masyarakat, LSM, perguruan tinggi maupun unsur lainnya. Alasan dari sisi pemerintah tidak melibatkan masyarakat adalah anggapan bahwa DPRD sudah merupakan wakil rakyat.

Manipulasi politik juga banyak dilakukan oleh pemerintah. Selain kasus penyimpangan proyek-proyek APBD, pemerintah daerah juga sering melakukan kompromi politik dengan DPRD dalam penyusunan kebijakan. Dalam setiap pembahasan produk hukum pasti terjadi deal-deal antara eksekutif dan legislatif, di mana eksekutif ingin agar legislatif menyetujui rancangan peraturan daerah yang diajukan. Konsekuensinya legislatif mendapatkan "apa" ketika menyetujui rancangan perda tersebut. Kondisi ini semakin mempersulit munculnya civil society yang kuat dan mandiri. Masyarakat yang berada dalam hegemoni pemerintah memerlukan peningkatan kapasitas, pemberdayaan dan pembelaan atas hak-haknya. Ketika partai politikpun tidak mampu menjadi wakil yang menyuarakan kebutuhan masyarakat, maka disinilah peran penting LSM dibutuhkan. LSM di Kalimantan Barat muncul sebagai akibat lemahnya kontrol dari lembaga-lembaga pengawasan seperti partai politik atau institusi pengawasan internal seperti inspektorat daerah. Partai politik dan lembaga-lembaga pengawasan dianggap lemah dalam menjalankan fungsi kontrol terhadap pemerintahan yang berkuasa, sehingga membiarkan terjadinya dominasi dan manipulasi pemerintah terhadap masyarakat. Dari sinilah gerakan LSM muncul secara alami sebagai reaksi atas kondisi sosial politik termasuk kondisi ekonomi.

Dalam praktiknya, dari empat peranan yang dapat dimainkan oleh LSM dapat diidentifikasikan peranan yang dijalankan LSM-LSM di Kalimantan Barat, yaitu: katalisasi perubahan sistem; memonitor pelaksanaan sistem dan penyelenggaraan negara; memfasilitasi rekonsiliasi warga dengan lembaga peradilan; dan yang terakhir adalah implementasi program pelayanan. Keempat peranan ini dilaksanakan dalam berbagai aksi dan kegiatan sebagaimana telah dipaparkan sebelumnya. Katalisasi perubahan sistem dilakukan dengan jalan mengangkat sejumlah masalah penting dalam masyarakat dan melakukan advokasi demi perubahan kebijakan pemerintah. Sedangkan implementasi program pelayanan dilakukan melalui sejumlah pelaksanaan kegiatan dan program di bidang pendidikan dan kesehatan serta proyek-proyek pemberdayaan masyarakat.

Dalam konteks hubungan LSM dengan pemerintah, dari kelima model hubungan antara LSM dengan pemerintah ada dua model hubungan yang cocok untuk menggambarkan pola hubungan antara LSM dengan pemerintah. Yang pertama adalah hubungan yang bersifat collaboration/ cooperation. Wujud kerjasama antara LSM dan pemerintah antara lain dalam bentuk pelatihan, sosialisasi, seminar dan dan kegiatan lain yang sifatnya meningkatkan kapasitas masyarakat. Contohnya kegiatan workshop pendidikan ramah anak, yang merupakan kerjasama LSM LPPBB (Lembaga Pemberdayaan Perempuan Bunga Bangsa Kalbar) bekerja sama dengan Kementerian Pendidikan Nasional dan Pemerintah Daerah Kalimantan Barat. Contoh lain advokasi (Perhimpunan Pekerja Kayu Hutan Hak Indonesia) yang bekerjasama dengan pemerintah dalam program Gerakan Nasional Anti Illegal Logging.

Dalam pola hubungan ini, pada praktiknya LSM melaksanakan program dan proyek-proyek pemerintah. Pemerintah menyediakan dana sedangkan LSM membantu dengan keahlian mereka. Namun, kebanyakan LSM jenis ini memiliki ketergantungan terhadap pemerintah terutama dari segi finansial dan pendanaan program. Pada akhirnya LSM berkewajiban melaksanakan seluruh program pemerintah sebagaimana yang telah ditentukan oleh pemerintah, tanpa mampu mengembangkan ataupun memberikan solusi terhadap permasalahan yang ada di lapangan. Oleh Fakih, LSM semacam ini dikritik sebagai LSM yang masih terkungkung dalam paradigma pembangunannisme (develop-mentalism) yang tidak kritis terhadap masalah-masalah ketimpangan struktural, partisipasi dan ketergantungan dari pihak luar. LSM yang seharusnya berperan sebagai aktor-aktor dalam gerakan sosial, justru menampakan diri sebagai agenagen subkontraktor pembangunan dari lembagalembaga milik pemerintah. LSM seharusnya memiliki sumber dana sendiri selain dari pemerintah, dalam melaksanakan program-program pemberdayaan dan pelayanan masyarakat.

Model kedua adalah hubungan yang bersifat containment/sabotage/dissolution. Dalam contoh kasus penangkapan beberapa aktivis LSM oleh aparat keamanan. Karena dianggap terlalu vokal, aktivis LSM sengaja dijebak oleh oknum pejabat 
pemerintah. Kasus lainnya, karena dianggap terlalu gencar membongkar sebuah kasus korupsi miliaran rupiah, seorang aktivis LSM menerima ancaman terhadap keselamatan jiwanya, sehingga sempat menghilang selama beberapa waktu sebelum kemudian terpaksa berkompromi karena merasa tidak mampu memberikan perlawanan.

Meskipun belum dalam skala besar, namun eksistensi LSM di Kalimantan Barat telah memberikan warna dalam upaya-upaya memperkuat civil society. Namun tidak semua LSM berperan sebagai pilar hadirnya civil society. Beberapa LSM justru melakukan tindakan yang menyimpang dari fungsinya. LSM-LSM tersebut justru berperan memperlemah gerakan rakyat dan melakukan kegiatan yang kontra-produktif. Umumnya motif penyimpangan perilaku sejumlah LSM adalah motif mencari keuntungan. Ketika peluang tersedia, berbagai cara dilakukan dengan memanfaatkan kedudukan dan posisi LSM dalam kehidupan politik di Kalimantan Barat. Contoh kasus penyimpangan yang dilakukan oleh LSM, di antaranya:

1. Bupati Pontianak dan Pimpinan DPRD sepakat untuk memberi dana APBD kepada Yayasan Bestari. Setelah APBD dicairkan, dana tersebut dibagikan kepada 45 orang anggota DPRD sebesar Rp 2,83 milyar. Sekelompok kontraktor yang merasa diperlakukan tidak adil dalam proses tender pembangunan melaporkan dugaan korupsi kepada Kejaksaan Negeri setempat. Kasus ini melibatkan LSM dalam jumlah yang cukup besar, setidaknya terdapat 37 organisasi masyarakat, tokoh masyarakat, pengacara, dan akademisi dengan total 332 pemberitaan di media massa.

2. Dalam pelaksanaan peran pengawasan, belakangan terjadi penyimpangan yang dilakukan oleh beberapa LSM. Pada praktiknya peran pengawasan hanya digunakan sebagai alat untuk mencari keuntungan. Sejumlah kalangan birokrat mengeluhkan perilaku sejumlah anggota LSM yang mendatangi mereka. Di depan para pejabat pemerintah daerah, oknum-oknum LSM ini mengungkapkan apa yang mereka sebut sebagai penyimpangan, kecurangan atau korupsi yang merugikan negara disertai dengan ancaman untuk melaporkan ke aparat hukum. Beberapa anggota LSM juga memiliki media cetak lokal, tidak jarang mereka menggunakannya sebagai alat penekan.

Dari uraian sebelumnya, terlihat bahwa misi mencari keuntungan materi merupakan motif utama yang mendasari penyimpangan perilaku LSM. Dari hasil wawancara menunjukan bahwa hampir semua LSM, terutama yang bergerak di bidang advokasi dan pengawasan tidak memiliki sumber dana yang jelas. Normatifnya, sumber dana didapatkan dari iuran para anggota, namun jika melihat latar belakang profesi para anggota LSM yang kebanyakan memiliki profesi dengan penghasilan yang tidak tetap, maka sulit bagi LSM untuk menjalankan operational sehari-hari dengan hanya mengandalkan iuran anggota. Apalagi jika dilihat dari jumlah anggota LSM yang kebanyakan kurang dari sepuluh orang, bahkan tidak jarang anggota yang aktif hanya ketua, sekretaris dan bendahara. Dapat dibayangkan seberapa besar dana yang dapat dikumpulkan untuk menghidupi dan membiayai aktifitas LSM. Para anggota LSM tentu harus berpikir bagaimana mencari dana paling tidak untuk membiayai operasional sehari-hari. Yang paling mudah adalah dengan memanfaatkan posisi LSM sebagai kelompok penekan pemerintah.

Profesionalisme aktivis LSM juga sangat diragukan, keterbatasan sumber dana menyebabkan tidak adanya standar gaji minimal bagi aktivis, atau bahkan tidak mendapatkan gaji sama sekali. Beberapa LSM hanya mengandalkan proyek dari pemerintah, dan ketika tidak ada proyek, maka LSM tersebut seperti mati suri, hingga muncul kembali ketika ada tawaran menangani proyek pemerintah daerah. Sedangkan dari sisi manajemen keuangan LSM, otorita keuangan biasanya dipegang oleh satu orang saja dan dana saldo kegiatan biasanya dibagibagi dikalangan anggota LSM, tidak untuk disimpan sebagai pendukung kegiatan lain. Akuntabilitas LSM dalam hal ini sangat lemah, karena umumnya mereka tidak membuat dan memiliki laporan keuangan resmi. Laporan keuangan dibuat hanya untuk kepentingan internal. Demikian juga dengan kantor dan sekretariat LSM, mayoritas LSM tidak mempunyai kantor tetap yang berdiri sendiri. Kebanyakan menggunakan rumah pimpinan atau anggota LSM sebagai alamat yang tercantum dalam akta pendirian LSM. Bahkan ada satu LSM yang mencantumkan rumah kontrakan sebagai sekretariatnya.

Dari segi tujuan didirikannya LSM dan program yang dijalankan, banyak LSM yang tidak jelas orientasi, visi dan misinya. Kebanyakan, kalaupun ada hanya di atas kertas dan bersifat normatif, bahkan cenderung didirikan hanya untuk memenuhi tujuan-tujuan tertentu. Di antaranya agar dapat mengerjakan proyek-proyek pemerintah. Seringkali ketika proyek-proyek APBD turun, mereka datang dengan setumpuk proposal untuk meminta proyek. Jika tidak diberi, maka seringkali terjadi praktik-praktik ancaman dan pemerasan. Dari hasil wawancara dengan para aktivis LSM diperoleh fakta bahwa, ketika ditanya mengenai tujuan didirikannya LSM, jawaban yang muncul adalah jawaban yang idealis, normatif dan terkesan mulukmuluk. Program kerja yang telah dilaksanakan tidak memiliki perencanaan dan umumnya bersifat insidental dan situasional tergantung jenis proyek yang didapatkan. Banyak LSM yang bahkan tidak memiliki program kerja yang kongkrit dan jelas.

Sementara itu dari mudahnya regulasi yang diberikan oleh pemerintah dalam mendirikan LSM, 
menyebabkan banyak LSM berdiri tanpa platform perjuangan dan program pelayanan yang jelas. Banyak LSM yang beroperasi bahkan tanpa prosedur hukum yang resmi, sedangkan pemerintah seakan membiarkan saja. Tidak adanya pengaturan dan pengendalian dari pemerintah menyebabkan banyak LSM bermunculan, akhirnya banyak LSM yang tidak memiliki sumber dana yang jelas dapat dengan mudah berdiri, hingga akhirnya melakukan berbagai penyimpang-an.

Persoalan utama terletak pada LSM itu sendiri, sehingga diperlukan adanya reposisi internal yang dilakukan dalam rangka pembenahan dan penataan kembali pranata dan sumber daya, termasuk sumber daya finansial. Masalah sumber dana adalah hal pertama yang harus diperhatikan untuk menciptakan LSM yang kuat, mandiri dan fokus terhadap program dan kegiatannya. LSM harus melakukan perubahan mendasar demi meningkatkan kapasitasnya, mulai dari orientasi, metode kerja, keahlian, pendekatan hingga jaringan kerja. Peningkatan kapasitas yang perlu dilakukan, yakni: 1) melalui penegasan ideologi dan orientasi; 2) peningkatan kapasitas menyimpan, mengembangkan dan memanfaatkan data; 3) peningkatan kemampuan untuk mengidentifikasikan dan bekerjasama, dengan institusi yang berbeda. Hal ini bukan hanya menyangkut kemampuan mengenali lembaga atau organisasi lain yang dapat diajak bekerjasama, tetapi juga kemampuan untuk membentuk kerjasama; 4) kemampuan meningkatkan pengetahuan dan pengalaman, serta kemampuan meng-evaluasi dan merekam pengalaman untuk didokumentasikan, dikomunikasikan dan dimanfaatkan oleh organisasi lain; dan 5) kemampuan meningkatkan akuntabilitas, yaitu bagaimana menerjemahkan peran dan fungsinya pada stakeholders yang berbeda.

Selain itu, LSM harus membangun kredibilitas dan identitasnya di mata masyarakat dan pemerintah. Citra buruk LSM harus dihilangkan, karena jika LSM masih terperangkap dalam motif sempit mencari keuntungan materi, maka seruan moral LSM menjadi tak berguna. LSM harus menegaskan identitasnya dengan memajukan prinsip-prinsip tertentu dan sekaligus menunjukan kepada masyarakat metode kerja mereka. LSM perlu memilih beberapa isu penting saja yang harus ditanganinya secara serius dan konsisten. LSM harus mengubah strategi dari melempar isu-isu menuju pada pemfokusan dalam pengembangan "desain alternatif", baik dalam skema formal maupun dalam bentuk informal. Dalam bentuk konkrit, adalah ikut serta dalam membentuk rancangan alternatif bagi pemerintah daerah dalam program tertentu.

Selain itu, Pemda Provinsi Kalimantan Barat juga perlu membuat aturan main yang jelas, bukan untuk mengawasi atau membatasi ruang gerak LSM, namun untuk menjamin profesionalisme LSM. Selama ini belum ada peraturan daerah yang mengatur tentang operasional LSM di Kalimantan
Barat. Semestinya ada perda yang mengatur lebih rinci mengenai sumber dana, keanggotaan minimal, syarat kantor atau sekretariat dan syarat-syarat administratif lainnya. Ketentuan dan sanksi bagi LSM yang tidak mempunyai SKT juga harus diperjelas. Semua ini penting agar LSM yang didirikan benar-benar berkualitas dan profesional dalam perannya sebagai pilar civil society.

\section{SIMPULAN}

Simpulan yang didapat dari pembahasan adalah sebagai berikut: Pertama, faktor-faktor menyebabkan penyim-pangan peran LSM, antara lain: mencari motif keuntungan; ketiadaan sumber dana dan rendahnya pro-fesionalisme; ideologi yang tidak jelas; dan regulasi yang belum ada.

Kedua,upaya-upaya yang dilakukan untuk mengembalikan peran LSM sebagai pilar civil society, antara lain melakukan perubahan mendasar demi meningkatkan kapasitasnya dan harus membangun kredibilitasnya di mata masyarakat dan pemerintah.

Berdasarkan simpulan yang didapat, maka saran yang disampaikan antara lain: Pertama, perlu undang-undang yang mengatur tentang LSM atau merevisi Undang-Undang Nomor 8 Tahun 1985 dengan mengatur Ormas dan LSM sekaligus. Kedua, sambil menunggu undang-undang tentang LSM atau revisi Undang-Undang Nomor 8 Tahun 1985, maka untuk menertibkan pembentukan dan operasionalisasi LSM serta pembinaannya, perlu diterbitkan kebijakan pemerintah untuk dijadikan sebagai pedoman pemerintah daerah dalam pembinaan LSM di daerah.

\section{DAFTAR PUSTAKA}

Fakih, Mansour, 1996, Masyarakat sipil untuk TransfOrmasi Sosial, Pergolakan Ideologi LSM Indonesia, Pustaka pelajar, Yogyakarta.

Gafar, Affan, 2006, Politik Indonesia, Transisi Menuju Demokrasi, Pustaka Pelajar, Yogyakarta.

Hikam, Muhammad AS, 1999, Demokrasi dan Civil Society, LP3ES, Jakarta.

Maruto, MD dan Anwari WMK (ed.). 2002. RefOrmasi Politik dan Kekuatan Masyarakat Kendala dan Peluang Menuju Demokrasi, LP3ES, Jakarta.

Nata Praja, Ageng, 2009. Distorsi Peran Lembaga Swadaya Masyarakat Dalam Perspektif Civil Society Di Kabupaten Grobogan, tesis, Universitas Diponegoro.

Sanit, Arbi, 1985, Swadaya Politik Masyarakat, CV. Rajawali, Jakarta;

Setiyono, Budi, 2003, Pengawasan Pemilu oleh LSM, Suara merdeka, 15 Oktober 2003.

Simon, Roger, 1999, Gagasan-gagasan Politik Gramsci, INSIST dan Pustaka Pelajar Offset, Yogyakarta

Suharko, 2005, Merajut Demokrasi Hubungan NGO, Pemerintah, dan Pengembangan Tata 
Pemerintahan Demokratis (1966-2001), Tiara Wacana Yogyakarta.

Sumber Internet:

Fickar Hadjar, Abdul, LSM, Demonstrasi \& Demokrasi, http://fickar15.blogspot.com/lsm-demonstrasidemokrasi.html, diunduh 15 Juli 2011.

\section{Sumber Perundang-Undangan:}

Instruksi Menteri Dalam Negeri (Inmendagri) Nomor 8 tahun 1990, tentang Pembinaan Lembaga Swadaya Masyarakat. 